\title{
Kilis Devlet Hastanesi Kanalizasyon Suyundan İzole Edilen Enterobacteriacea Suşlarının Antibiyotik Dirençlilik Profilleri
}

\author{
Antibiotic Resistance Profiles of Enterobacteriacea Strains Isolated from Kilis State Hospital \\ Sewage Water
}

\author{
Hatice Aysun MERCIMEK TAKCI ${ }^{1}$ (D) , Pemra BAKIRHAN² (D) , Melike KAPTANOĞLU ${ }^{3}$ (D) , Sema GENÇ \\ ${ }^{1}$ Kilis 7 Aralı Üniversitesi, Moleküler Biyoloji ve Genetik Bölümü, 79000, Kilis, Türkiye \\ ${ }^{2}$ Kilis 7 Aralık Üniversitesi, Moleküler Biyoloji ve Genetik Anabilim Dalı, 79000, Kilis, Türkiye \\ ${ }^{3}$ Kahramanmaraş Sütçü Imam Üniversitesi, Biyoloji Anabilim Dall, 46040, Maraş, Türkiye
}

$\ddot{O} \mathbf{z}$

Kilis Devlet Hastanesi kanalizasyon suyundan MacConkey besi ortamı kullanılarak Enterobacteria familyasına ait suşlar izole edilmiştir. Laktozu parçalama özelliklerine göre toplamda 30 bakteri suşu seçilmiştir. Seçilen suşlar morfolojik karakterleri ve biyokimyasal aktivitelerine göre tanımlanmıştır. Biyokimyasal test sonucuna göre Escherichia coli (Biyotip I ve II)-(Ara tip I ve II), Klebsiella spp. ve Citrobacter spp. suşları içeren 20 suşun kısmi tiplendirilmesi yapılmıştır. Tiplendirilen 20 suştan farklı aktiviteler gösteren 8 suş seçilerek antibiyotik dirençlilik profilleri belirlenmiştir. Seçilen 8 bakteri suşu için farklı etki mekanizmalarına sahip 11 antibiyotik test edilmiştir (klindamisin, trimethoprim, kloramfenikol, eritromisin, tetrasiklin, streptomisin, amfisilin, sefotaksim, vankomisin, gentamisin ve sefoperazon). Test tüm suşlar için MAR indeksi 0.2'nin üzerinde olduğu bulunmuş olup, en yüksek ÇAD indeksi Escherichia coli Biyotip I ve Citrobacter spp suşlarında 0.75 olarak hesaplanmıştır.

Anahtar Kelimeler: Kanalizasyon suyu, Antibiyotik dirençlilik, ÇAD indeksi, Enterobacteriaceae

\begin{abstract}
Enterobacteria strains were isolated from the sewage water of Kilis State Hospital by using MacConkey medium. A total of 30 bacterial strains were selected according to their lactose degradation properties. The selected strains were identified by their morphological characteristics and biochemical activities. Association with the biochemical tests, 20 strains including Escherichia coli (Biotype I, II), Klebsiella spp and Citrobacter spp strains were partially identified. Antibiotic resistance profiles were determined by selecting 8 strains with different activities from 20 isolates. 11 antibiotics with different effect mechanisms were tested against the selected 8 bacterial strains (clindamycin, trimethoprim, chloramphenicol, erythromycin, tetracycline, streptomycin, ampicillin, cefotaxime, vancomycin, gentamicin and cefoperazone). The MAR index for all tested strains was found to be over 0.2 and the highest MAR index was 0.75 for Escherichia coli Biotype I and Citrobacter spp.
\end{abstract}

Keywords: Sewage water, Antibiotic resistance, MAR index, Enterobacteriaceae

\section{GİRIŞ}

Bakteriler bölünmelerine devam edebilmeleri için ekolojik niş açısından oldukça geniş yelpazeye sahip mikroorganizmalardır. Hayatımızın bir parçası haline gelen bu mikroorganizmalar çoğu zaman yararlı halde bulunurken bazen ise zararlı bir hal alabilmektedirler. Topraklarda, denizlerde, sıcak su kaynakları gibi doğal ortamlarda bulunan bu mikroorganizmaların kanalizasyon suyunda da bulunma olasılıkları oldukça yüksektir. Kanalizasyon sularında bulunan katı atıklar, önemli miktarda inorganik maddeyle birlikte biyolojik olarak çözünebilir organik maddeleri içermelerinden dolayı bakteri suşlarının büyüyüp gelişmesi için önemli bir ortam özelliği taşımaktadır [1]. Bu kadar organik, inorganik madde ve patojen mikroorganizmanın 
bol olduğu ortam insan ve diğer canlıların sağlığı açısından büyük bir tehdit oluşturmaktadır. Sadece bunlarla sınırlı kalmayıp içerisinde bulundurduğu bakterilerin bazı toksik maddeleri üretmesiyle de çeşitli hastalıklara sebebiyet verebilmektedir [2].

Enterobacteriacea kanalizasyon suyunda, insan ve hayvanların intestinal florasında sıkça rastlanan, klinik örneklerden de enfeksiyon etkeni olarak sıkça izole edilmektedir [3]. Gram negatif (-) çomak şeklinde çok geniş olan bu aile grubunda yer alan bazı suşlar zararsız olabilecekleri gibi, yatan hastalarda, immün sistemi baskılanmış kişilerde, geriatrik gruplarda ya da invaziv işlem geçiren kişilerde ciddi enfeksiyonlara yol açabilirler [4]. Ayrıca Enterobacteriacea türleri fakültatif aneorob olup şekeri fermente edebilen katalaz pozitif, oksidaz negatif ve nitratı nitrite indirgeme kapasitelerine sahip bakterilerdir [5]. Enterobacteriacea ailesine ait $E$. coli ilk kez 1885 yılında keşfedilmiş olup günümüzde hala birçok çalışmada kullanılan bakteri suşudur. Fakültatif aerobik gram negatif $E$. coli'nin yanı sıra idrar yolu enfeksiyonuna neden olan Salmonella ve Klebsiella spp. aynı ailenin farklı grupları olarak örnek gösterilebilir. Birçok türü beta laktamaz üreticisi olan bu bakteriler klinik açıdan ve laboratuar araştırmaları açısından sıklıkla tercih edilmektedirler. Bu bakterilerin genişlemiş spektrumlu beta laktamaz ve metallo-beta laktamaz üretimi hastalıkların tedavi sürecini yavaşlatarak çoklu antibiyotik dirençli suşların ortaya çıkmasına sebep olmaktadır.

$\mathrm{Bu}$ çalışmada Kilis Devlet hastanesi kanalizasyon suyundan izole edilen Enterobacteriacea suşlarının çeşitli etki mekanizmalarına sahip antibiyotiklere karşı dirençliliklerinin araştırılması amaçlanmıştır.

\section{MATERYAL METOD}

Kilis Devlet Hastanesinden steril koşullarda alınan kanalizasyon suyu örneği bakteri izolasyonu için laboratuvara getirilmiştir. Kanalizasyon suyundan fizyolojik tuzlu su (\%0.9 $\mathrm{NaCl}$ ) kullanılarak bir seri sulandırmalar hazırlanmış ve $10^{-}$ $1,10^{-3}, 10^{-5}$ ve $10^{-7}$ sulandırmaların $100 \mu$ L'si MacConkey ve EMB besiyerlerine steril drigalski özesi ile inoküle edilip $37^{\circ} \mathrm{C}$ 'de $12-24$ saat inkübasyona bırakılmıştır. İnkübasyon sonra MacConkey besiyerinde laktozu fermente eden tek düşmüş koloniler seçilmiştir. Bakteri suşları gram boyanma, metil kırmızı, voges proskauer, sitrat, 4-Methylumbelliferyl- $\beta$-D-Glucuronide (MUG) ve Triple Sugar Iron (TSI) testi gibi biyokimyasal testlerine tabii tutularak tanımlanmıştır.

Antibiyotik dirençlilik testleri Kirby-Bayer disk difüzyon yöntemi kullanılarak sürdürülmüştür. Luria Bertani besiyerinde geliştirilen 24 saatlik kültürlerin optik yoğunluğu steril fizyolojik tuzlu su ile 0.5 Mac Farland standard bulanıklığına ayarlanmıştır. Bu süspansiyon steril eküvyon çubuğu ile Mueller Hinton agar besiyerine inoküle edilmiştir. Klindamisin (CD) (2 mcg/disk), Trimethoprim (TR) (5 mcg/ disk), Kloramfenikol (C) (30 mcg/disk), Eritromisin (E) (15 $\mathrm{mcg} /$ disk), Tetrasiklin (TE) (30 mcg/disk), Streptomisin (S) (10 mcg/disk), Ampisilin (AMP) (10-mcg/disk), Sefotaksim (CTX) (30-mcg/disk), Vankomisin (VA) (30-mcg/disk), Gentamisin (GEN) (10-mcg/disk), Sefaparazom (CPZ) (75$\mathrm{mcg} / \mathrm{disk}$ ) antibiyotik diskleri eşit aralıklarla besiyerine yerleştirilmiştir. $37^{\circ} \mathrm{C}$ 'de $18-24$ saat inkübasyonu takiben disklerin etrafında bakterilerin üremediği şeffaf zonların varlığı incelenmiştir.

European Committee on Antimicrobial Susceptibility Testing (EUCAST) tarafindan ifade edilen hassasiyet/direnç zon çaplarına göre kullanılan antibiyotiklerin söz konusu klinik izolat üzerindeki etkileri değerlendirilmiştir (Tablo 1).

Tablo 1. Antibiyotik dirençlilik test sistemi için EUCAST referans değerleri

\begin{tabular}{|l|l|l|l|}
\hline & $\begin{array}{l}\text { Duyarlılık } \\
\text { (S) }\end{array}$ & $\begin{array}{l}\text { Orta Dirençli } \\
\text { (I) }\end{array}$ & $\begin{array}{l}\text { Dirençlilik } \\
\text { (R) }\end{array}$ \\
\hline Kloramfenikol $(30 \mathrm{mcg} /$ disk $)$ & $\geq 18$ & $13-17$ & $\leq 12$ \\
\hline Klindamisin $(2 \mathrm{mcg} /$ disk $)$ & $\geq 21$ & $15-20$ & $\leq 14$ \\
\hline Sefotaksim $(30 \mathrm{mcg} /$ disk $)$ & $\geq 26$ & $23-25$ & $\leq 22$ \\
\hline Sefaparozom $(75 \mathrm{mcg} /$ disk $)$ & $\geq 21$ & $16-20$ & $\leq 15$ \\
\hline Amfisilin $(10 \mathrm{mcg} /$ disk $)$ & $\geq 17$ & $14-16$ & $\leq 13$ \\
\hline Vankomisin $(30 \mathrm{mcg} /$ disk $)$ & $\geq 17$ & $15-16$ & $\leq 14$ \\
\hline Streptomisin $(10 \mathrm{mcg} /$ disk $)$ & $\geq 15$ & $12-14$ & $\leq 11$ \\
\hline Tetrasiklin $(30 \mathrm{mcg} /$ disk $)$ & $\geq 15$ & $12-14$ & $\leq 11$ \\
\hline Trimethoprim $(5 \mathrm{mcg} /$ disk $)$ & $\geq 18$ & $16-17$ & $\leq 15$ \\
\hline Gentamisin $(10 \mathrm{mcg} /$ disk $)$ & $\geq 17$ & $15-16$ & $\leq 14$ \\
\hline Eritromisin $(15 \mathrm{mcg} /$ disk $)$ & $\geq 23$ & $14-22$ & $\leq 13$ \\
\hline
\end{tabular}

\section{BULGULAR ve TARTIŞMA}

MacConkey besi yerinde koloni görünümü renksiz, yar1-saydam olanlar Salmonella, Shigella; büyük, kırmızı, etrafı bulanık zon ile çevrili olanlar Escherichia coli; büyük, pembe, mukozlu olanlar Enterobacter, Klebsiella; çok küçük opak tek koloniler ise Enterococci; olarak değerlendirilmiştir. Laktozu kullanan bakteriler, asidik ürünler nedeniyle besiyeri $\mathrm{pH}$ 'sının düşmesine ve $\mathrm{pH}$ indikatörünün renk değiştirmesine bağlı olarak koyu renkli koloniler oluşturmuştur. Bu koloniler laktoz pozitif koloniler olarak değerlendirilmiştir. Laktozu kullanmayan bakteriler ise bu besiyerlerinde renksiz, şeffaf koloniler oluştururlar ve laktoz negatif olarak tanımlanmıştır. Laktozu parçalayan 30 kanalizasyon izolatı seçilmiş ve nutrient agar çizgi ekim şeklinde 
stoklanmıştır. Bakteri suşlarının gram boyanma davranışları test edilmiş ve gram negatif (-) basil oldukları belirlenmiştir.

IMVIC (Indol, Metil kırmızıs1, Voges Proskauer ve Sitrat) testi sonuçlarına göre benzer biyokimyasal aktivite gösteren izolatlardan 20'si seçilmiş ve TSI testi uygulanmıştır. İzolatların karbonhidratı parçalayıp ortamın $\mathrm{pH}$ 'sını asitleştirerek sarı renk oluştururken, besiyerinde parçalanma görülmesi gaz oluşumunu göstermiştir. TSI sonuçlarına göre M1, M14, M15, M24, M25, M34, K35, OS51, OS54, OS55 ve OS57 olarak isimlendirilen izolatlar TSI agarda karbon kaynağını parçalamış ve oluşturduğu asit ürünleri ile fenol kırmızısı indikatörünün rengini değiştirerek besiyerini sarı renge çevirmiştir. M16, M17, M21, M26, M27, K31 ve K36 izolatları ise besiyerindeki karbon kaynağını parçalamış fakat oluşturdukları nötral ürün sebebiyle besiyerinde renk değişimi gözlenmemiştir.

TSI agarda karbohidrat fermantasyonu incelenmiş 20 izolata MUGaz testi uygulanmıştır. MUG enzimi substrat1 MUG (4-Methyleumbelliferyl- $\beta$-D-glucuronide) transimilatörde 365-366 nm dalga boyuna sahip UV 1şı̆̆ altında floresan 1şığı veren bir bileşiğe (methylumbelliferone) parçalamaktadır. MUGaz aktivitesi, izolatlar arasında $E$ coli'nin tanımlanması amacıyla test edilmiştir. MUG sonuçlarına göre: M1, M2, M14, M15, M23, M24, M25, K34, K35, OS51, OS54, OS55 ve OS57 izolatlarının kültürleri uv 1şığ 1 altında floresan 1şıma vermiştir. M16, M17, M21, M26, M27, K31 ve K36 suşlarının kültürleri ise uv ışığı altında floresans renk vermemiştir.

Gr boyanma, IMVIC, TSI ve MUG testlerinden elde edilen sonuçlara göre kanalizasyon izolatları kısmi olarak tiplendirilmiştir. Buna göre M1, M24, M25, OS54, OS55, OS57 ve K34 E. coli (Biyotip I); M2 ve M15 E. coli (Biyotip II); K35 ve OS51 E. coli (Aratip II); M14 E. coli (Aratip I); M16, M17 ve M27 Klebsiella spp.; M21, M26, K31 ve K36 ise Citrobacter spp. olarak tanımlanmıştır.

M16, M17 ve M27 izolatlarının nigrosin çözeltisi ile kapsül boyaması yapılmıştır. Boyama sonrası M16, M17, M27 izolatlar da siyah zemin üzeri parlak zon şeklinde görüntülenmiştir. $\mathrm{Bu}$ izolatlar besi ortamında mukoid koloni oluşturmaları ve kapsüllü olmaları sebebiyle Klebsiella spp. olarak tanımlanmıştır.

Tarımsal ve endüstriyel uygulamalardan elde edilen atık sular, kanalizasyon patojenleri arasındaki koliform bakterilerin yayılması için önemli bir kaynaktır. Bu nedenle literatürde de belirtildiği gibi söz konusu çalışmalar genelde şebeke suları veya endüstriyel atık suların mikrobiyal kalitesinin belirlenmesine yönlenmiş̦tir. Muş ve Çetinkaya tarafindan (2015) yapılan çalışmada Bursa ili ve ilçelerinde tüketim ve kullanım sularının mikrobiyolojik yükü belirlenmiştir. Toplam 200 adet su örneğinden fekal indikatör bakterilerin varlığı tespit edilmiştir. Kurt ve ark. (2009) 7132 adet içme-kullanma suyu örneklerinden 844'ünün koliform bakteri içerdiğini bildirmiştir. 2495 içme suyu örneğinin incelendiği diğer bir çalışmada ise 119 örnekte E. coli (fekal koliform) ve 223 örnekte ise total koliform tespit edilmiştir [8]. Behesheti Maal ve ark. (2015) Isfahan belediye atık su uygulama tesisinde $E$. coli varlığına işaret etmektedir. Farklı arıtma tesislerinden alınan örneklerde Zwenger ve Gillock (2009) moleküler teknikler kullanarak koliform ve fekal koliform bakterilerin varlığını ortaya koymuşlardır [2]. Nandyal Kurnool belediye atık sularında gram negatif basil ve kok, gram pozitif kok ve basil bakterileri izole etmişlerdir.

Biyokimyasal test sonuçlarına göre benzer metabolik aktivite gösteren 20 izolattan M14, M15, M16, M21, M26, K36, OS51 ve OS57 olarak isimlendirilen izotlar seçilmiş ve bu izolatlar ile antibiyogram analizi sürdürülmüsstür. Antibiyotik zon çapları Tablo 1'de verilen EUCAST verilerine göre değerlendirilmiştir. Suşların test edilen standart antibiyotiklere karşı gösterdiği davranışlar Şekil 1 ve Tablo 2'de verilmiştir.

Tablo 2. Standart antibiyotiklerin suşlara karşı antibakteriyel aktivitesi ( $\mathrm{mm}$ cinsinden zon çapı)

\begin{tabular}{|c|c|c|c|c|c|c|c|c|c|c|c|}
\hline & & $\mathbf{E}$ & TR & C & CPZ & GEN & $\mathbf{V A}$ & TE & AMP & CTX & CD \\
\hline M14 & $18^{S}$ & ${ }^{*} \mathrm{R}$ & ${ }^{*} \mathrm{R}$ & $23^{S}$ & $18^{\mathrm{R}}$ & $15^{\mathrm{R}}$ & $30^{\mathrm{S}}$ & $23^{S}$ & $-{ }^{*} R$ & $15^{\mathrm{R}}$ & ${ }_{-}^{*} \mathrm{R}$ \\
\hline 15 & & $18^{\mathrm{R}}$ & $28^{\mathrm{S}}$ & 2. & & $2^{\mathrm{R}}$ & & $2^{\mathrm{R}}$ & $-{ }^{*} \mathrm{R}$ & $=\mathrm{R}$ & ${ }^{*} \mathrm{R}$ \\
\hline M16 & & $S$ & $28^{S}$ & $7^{\mathrm{R}}$ & $28^{\mathrm{S}}$ & $7^{R}$ & $7^{\mathrm{R}}$ & $6^{\mathrm{R}}$ & $18^{\mathrm{S}}$ & $-{ }^{*} R$ & ${ }_{-}^{*} \mathrm{R}$ \\
\hline $2 !$ & 3 & $5^{\mathrm{R}}$ & $5^{\mathrm{R}}$ & $28^{\mathrm{S}}$ & & $22^{S}$ & $\overline{9^{\mathrm{B}}}$ & $2^{\mathrm{R}}$ & $-{ }^{*} R$ & ${ }_{-}^{*} R$ & $3^{\mathrm{R}}$ \\
\hline M26 & & $15^{\mathrm{R}}$ & $5^{\mathrm{R}}$ & $3^{\mathrm{R}}$ & 新 & $3^{\mathrm{R}}$ & $11^{\mathrm{R}}$ & $12^{\mathrm{R}}$ & ${ }_{-}^{*} R$ & $-{ }_{-}^{*} R$ & $6^{\mathrm{R}}$ \\
\hline 6 & & $8^{S}$ & $-{ }^{*} R$ & $32^{\mathrm{S}}$ & $18^{\mathrm{R}}$ & $2^{\mathrm{R}}$ & $12^{\mathrm{R}}$ & $18^{\mathrm{S}}$ & $-{ }^{*} R$ & $18^{\mathrm{R}}$ & $-{ }^{*} \mathrm{R}$ \\
\hline OS5 & $25^{\mathrm{S}}$ & $-{ }^{*} R$ & $25^{\mathrm{S}}$ & $27^{\mathrm{S}}$ & $-{ }_{-}^{*} R$ & $15^{\mathrm{R}}$ & $15^{\mathrm{R}}$ & $2^{\mathrm{R}}$ & $-{ }_{-}^{*} R$ & $-{ }^{*} \mathrm{R}$ & $-{ }^{*} R$ \\
\hline OS57 & $11^{\mathrm{R}}$ & $7^{\mathrm{R}}$ & ${ }_{-}^{*} \mathrm{R}$ & $-{ }^{*} \mathrm{R}$ & $-{ }^{*} R$ & $17^{\mathrm{S}}$ & $18^{\mathrm{S}}$ & $2^{\mathrm{R}}$ & $-{ }^{*} \mathrm{R}$ & $-{ }_{-}^{*} R$ & $-{ }^{*} R$ \\
\hline
\end{tabular}

*: Zon çapı gözlemlenmemiştir.

S: Europan Commitee on Antimicrobial Susceptibility Testing (EUCAST)'a göre belirlenmiş hassasiyet

R: Europan Commitee on Antimicrobial Susceptibility Testing (EUCAST)'a göre belirlenmiş dirençlilik

Tablo 2'de gözlendiği gibi amfisiline karşı M16 hariç diğer test bakterileri dirençlilik gösterirken, sefotaksim ve klindamisin'e karşı tüm bakteriler direnç göstermektedir. Kloramfenikol'e karşı M16, M26, OS57 izolatları dirençlilik gösterirken diğer test bakterileri hassasiyet göstermiştir. Sefaparozom'a M14, M15, M21, M26, OS51 ve OS57 suşları dirençlilik göstermiş M16 suşu ise hassasiyet göstermiştir. Vankomisin'e M14 ve OS57 suşları hassasiyet gösterirken diğerleri dirençlilik göstermiştir. Tetrasiklin'e karşı M14 ve K36 izolatları hassasiyet göstermiş̧ir. Diğer test organizmaları ise dirençlidir. Streptomisin'e karşı M21 ve OS57 suşları dirençlilik gösterirken diğer test organizmaları antibiyotiğe karşı hassastır. Eritromisine karşı M16 hariç tüm bakteriler dirençlidir. Trimetropim'e karşı M15, 
M16 ve OS51 suşları; Gentamisin'e karşı ise M21 ve OS57 suşları hassastır (Şekil 1).

Test bakterilerinin dirençli olduğu antibiyotik sayısının total incelenen antibiyotik sayısına oranlanması ile belirlenen MAR (multiple antibiotic resistance) indeksi hesaplanmıştır (Tablo 3).

MAR indeksi en yüksek bakteriler OS57 ve M21 olup kanalizasyon izolatlarının MAR indeksi 0.2 referans değerinin üzerindedir. MAR indeksinin 0.2'nin üzerinde olması kanalizasyon izolatlarının çoklu antibiyotik direnci gösterdiklerini ifade etmektedir.
Tablo 3. İzolatların MAR indeksi

\begin{tabular}{|l|l|}
\hline & MAR indeksi \\
\hline M14 & 0.41 \\
\hline M15 & 0.50 \\
\hline M16 & 0.50 \\
\hline M21 & 0.75 \\
\hline M26 & 0.67 \\
\hline K36 & 0.58 \\
\hline OS51 & 0.58 \\
\hline OS57 & 0.75 \\
\hline
\end{tabular}
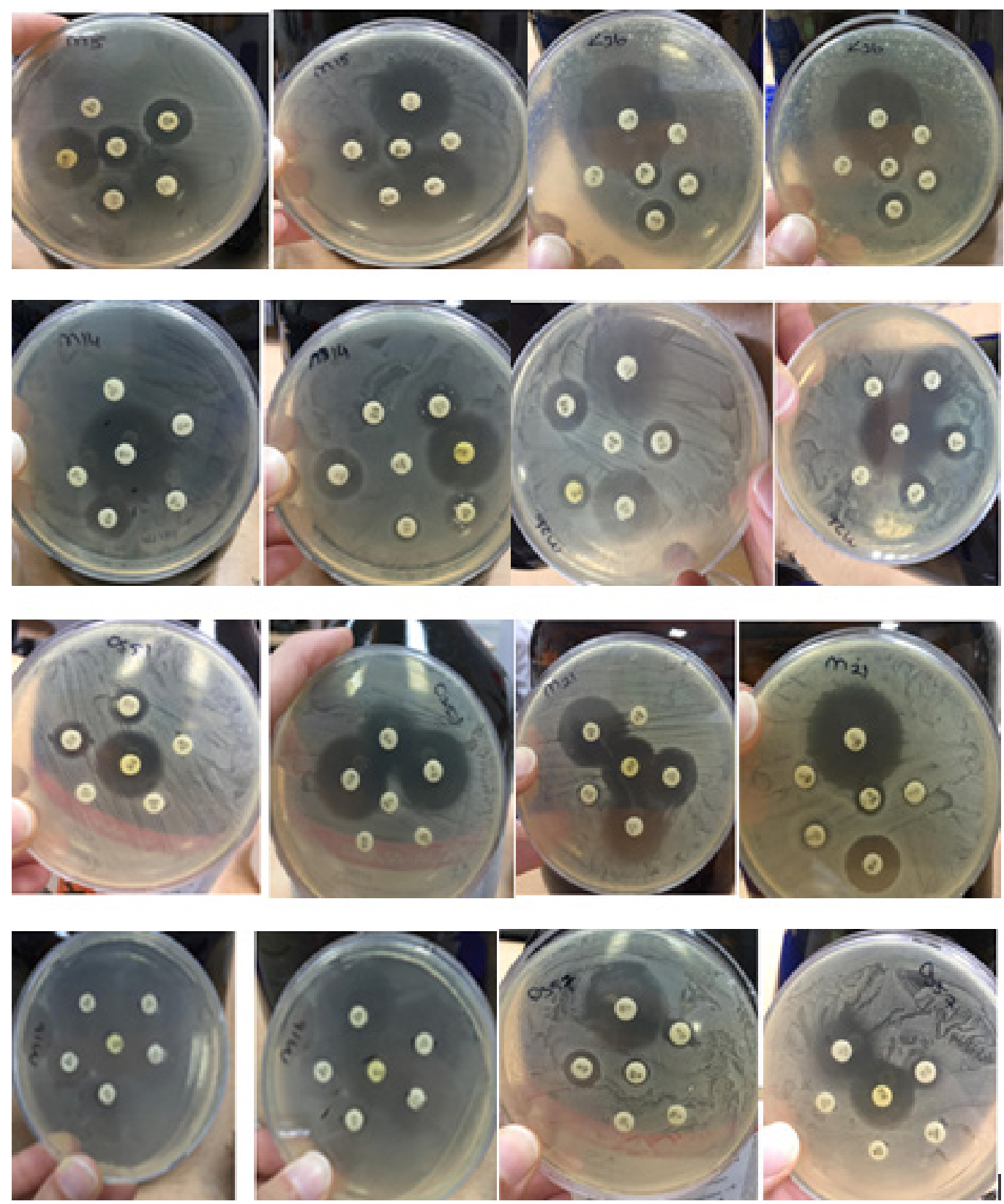

Şekil 1. Kanalizasyon izolatların antibiyotik dirençlilik profilleri 
Reinthaler ve ark., (2003) atık su arıtım tesislerinden izole ettikleri $767 \mathrm{E}$. coli suşunun 26 farklı antibiyotiğe karş1 dirençlilik profillerini belirlemişlerdir. Test edilen antibiyotikler arasında en yüksek direnç oranı çalışmamıza benzer şekilde amfisiline karşı gözlenmiştir. 2004-2005 kış periyodu süresince hastane atık sularından Klebsiella spp., Citrobacter spp. ve E. coli suşlarını içeren 69 enterik bakteri izole edilmiş ve 51 enterik suşun sonuçlarımızı destekler nitelikte amfisiline karşı dirençli olduğu ortaya konmuştur [12]. Çalışmamızın sonuçlarına benzer olarak diğer bir çalışmada ise 13 atık su arıtım tesisinde tetrasiklin ve beta-laktam dirençli E. coli popülasyonuna rastlanmıştır [13].

Bolaji ve ark. (2011) Nijerya'da seçilen hastane atık sularından izole ettikleri enterik bakterilerin kloramfenikol, streptomisin ve gentamisin antibiyotiklerine karşı dirençli olduklarını gözlemlemişlerdir. Benzer sonuçlar Nikaragua'da hastane atık sularından amfisilin, kloramfenikol ve trimetropimin test edildiği çalışmada kaydedilmiş olup, yüksek seviyede antibiyotik dirençliliği gösteren $E$. coli suşları izole edilmiştir [15]. Tayvan'da sürdürülen diğer bir çalışmada ise hastane atık suyu ve klinik izolatların dirençlilik profilleri karşılaştırılmış ve atık su izolatlarının daha yüksek antibiyotik direnç oranına sahip olduğu ortaya konmuştur. Çalışmamıza benzer şekilde amfisilin antibiyotiğine karşı yüksek dirence işaret edilmiştir [16]. Moges ve ark (2014), Kuzeybatı Etiyopya'daki hastane atık sularından Klebsiella spp., Pseudomonas spp., E. coli, Citrobacter spp. ve Staphylococcus spp. suşlarını içeren 65 izolatın antibiyotik dirençlilik profillerini araştırmıştır. Çalışmamıza benzer olarak test edilen antibiyotiklere karşı çoklu ilaç direncine işaret edilmiştir. Hastane atık sularından izole edilen 3 adet suşun amoksisilin, amfisilin, tetrasiklin, ofloksasin, kloramfenikol ve siprofloksasin antibiyotiklerinin tümüne karşı dirençli olduğu tespit edilmiştir [18]. Akkan ve ark. (2011) hastane atık sularının deşarj edildiği deniz suyundan izole ettikleri 85 gram negatif bakterinin sefalosporin grubu antibiyotiklere karşı direnç düzeylerini; sefazoline $\% 85$, sefuroksime $\% 28$, sefotaksime $\% 8$ ve sefepime $\% 5$ oranında rapor etmişlerdir.

Bu çalışmada Kilis ili Devlet Hastanesi hastane atık sularından E. coli (Biyotip I-II ve Aratip I-II) Klebsiella spp. ve Citrobacter spp. suşlarını içeren 8 izolatın antibiyotik dirençlilik profilleri test edilmiştir. Test edilen klindamisin, trimethoprim, kloramfenikol, eritromisin, tetrasiklin, streptomisin, amfisilin, sefotaksim, vankomisin, gentamisin ve sefaparazom antibiyotiklere karşı suşlar direnç göstermiş ve çoklu antibiyotik direncine sahip oldukları ortaya konmuştur. İnsan ve endüstriyel kaynaklı atık suların çevreye verilmesi ve yer altı sularına karışması sonucu, çalışmamızda elde edilen çoklu ilaç direncine sahip bakterilerin içme suyu olarak değerlendirilen kuyu suları ile etkileşimi mikrobiyal kirliliğin yayılmasına sebep olacaktır.

\section{KAYNAKLAR}

[1] Wan Ishak, W.M.F., Jamek S., Jalanni N.A., \& Mohd Jamaludin, N.F., (2011). Isolation and Identification of Bacteria from Activated Sludge and Compostfor Municipal Solid Waste Treatment System. International Proceedings of Chemical, Biological and Environmental Engineering, 24, 450454.

[2] Mahesh, S., Aleem Basha, P., \& Kavitha B., (2017). Isolation and Characterization of Bacteria Izolated From Municipal Sewage Water of Nandyal Kurnool, A.P., India. Asian Journal of Microbiology, Biotechnology and Environmental Sciences, 19(3), 772-777.

[3] Kılıç, Ü., (2018). Karbapenemaz Üreten Enterobactericea Kökenlerinde Çeşitli Antibiyotik Kombinasyonlarının in vitro Etkinliklerinin Araştırılması. Uzmanlık tezi, Sakarya Üniversitesi, Türkiye, 81 .

[4] Halipçi Topsakal, H.N., (2018). İnvazif Enfeksiyonlara Neden Olan Genişlemiş Spektrumlu Beta-Laktamaz (GSBL) Oluşturan Enterobacteriaceae İzolatlarının Hızlı Teşhisi için DNA Aptamerlerinin Geliştirilmesi. Doktora tezi, Kahramanmaraş Sütçü İmam Üniversitesi, Türkiye, 106.

[5] Abdünnur, V., (2016). İstanbul'da Satışa Sunulan Dondurmaların Listeria monocytogenes ve Enterobacteriaceae Varlığ Yönünden İncelenmesi. Yüksek Lisans Tezi, İstanbul Aydın Üniversitesi, Türkiye, 107.

[6] Elal Mus, T., \& Cetinkaya, F., (2015). Investigation of the Presence of Indicator and Some Pathogenic Bacteria in Drinking and Usage Waters in Bursa. Soil Water Journal, 6(1), 1-6.

[7] Kurt, A.Ö., Şaşmaz, Tç, Buğdaycı, R., Öner, S., \& Kızılok, A., (2009). Mersin ili içme kullanma suyu numunelerinin bakteriyolojik yönden değerlendirilmesi. Türkiye Halk Săglı̆̆ $\breve{l}_{\text {Dergisi, }}$ (1), 23-31.

[8] Avc1, S., Bakıc1, M.Z., \& Erandaç, M., (2016). A Research on Drinking Water in Tokat in Terms of Coliform Bacteria. Cumhuriyet Üniversitesi Tıp Fakültesi Dergisi, 28(4), 107-112

[9] Behesheti Maal, K., Soleimani Delfan, A., \& Salmanizadeh, S., (2015). Isolation and Identification of Two Novel Escherichia coli Bacteriophages and Their Application in Wastewater Treatment and Coliform's Phage Therapy. Jundishapur Journal of Microbiology, 8(3), e14945

[10] Zwenger, S.R., \& Gillock, E.T., (2009). Bacteria Isolated from Sewage Influent Resistant to Ciprofloxacin, Chloramphenicol and Tetracycline. Journal of Environmental Science and Health, Part A, 44, 123-129.

[11] Reinthaller, F.F., Posch, J., Feierl, G., Wüst, G., Haas, D., Ruckenbauer, G., Mascher, F., \& Marth, E., (2003). Antibiotic resistance of E. coli in sewage and sludge. Water Research, $37,1685-1690$. 
[12] Alam, M.Z., Aqil, F., Ahmad, I., \& Ahmad, S., (2013). Incidence and Transferability of AntibioticRresistance in the Enteric Bacteria Isolated from Hospital Waste Water. Brazilian Journal of Microbiology, 44(3), 799-806

[13] Osińska, A., Korzeniewska, E., Harnisz, M., \& Nestẹpski, S., (2019). Quantitative Occurrence of Antibiotic Resistance Genes among Bacterial Populations from Wastewater Treatment Plants Using Activated Sludge. Applied Sciences, 9(387), 1-15.

[14] Bolaji, A.S., Akande, I.O., Iromini, F.A., Adewoye, S.O., \& Opasola, O.A., (2011). Antibiotic resistance pattern of bacteria spp isolated from hospital waste water in Ede South Western, Nigeria. European Journal of Experimental Biology, 1(4), 66-71.

[15] Amaya, E., Reyes, D., Paniagua, M., Calderón, S., Rashid, M.U., Colque, P., Kühn, I., Möllby, R., Weintraub, A., \& Nord, C.E., (2012). Antibiotic Resistance Patterns of Escherichia Coli Isolates from Different Aquatic Environmental Sources in León, Nicaragua. Clinical Microbiology and Infection, E347-E354
[16] Yang, C.M., Lin, M.F., Liao, P.C., Yeh, H.W., Chang, B.V., Tang, T.K., Cheng, C. Sung, C.H., \& Liou, M.L., (2009). Comparison of Antimicrobial Resistance Patterns Between Clinical and Sewage Isolates in a Regional Hospital in Taiwan. Letters in Applied Microbiology, 48, 560-565.

[17] Moges, F., Endris, M., Belyhun, Y., \& Worku, W., (2014). Isolation and characterization of multiple drug resistance bacterial pathogens from waste water in hospital and non-hospital environments, Northwest Ethiopia. BMC Research Notes 7(215), 1-6.

[18] Pandey, A., Afsheen, Ara, F., \& Tiwari, S.K., (2011). Isolation and Characterization of Multi Drug Resistance Cultures from Waste Water. Journal of Pharmaceutical and Biomedical Sciences, (JPBMS) 13(14), 1-15.

[19] Akkan, T., Kaya, A., \& Dinçer, S., (2011). Rate of Cephalosporin Resistance in Gram-Negative Bacteria Isolated from Hospital Sewage Contaminated Seawater. Türk Mikrobiyoloji Cemiyeti Dergisi, 41(1), 18-21. doi:10.5222/TMCD.2011.018 